\title{
Offering Appropriate Information Technologies at Different Stages in the Customer Service Life Cycle for Improved Service Delivery
}

\author{
Jennifer E. Gerow, Janis Miller \\ Clemson University, Clemson, USA. \\ Email: jgerow@clemson.edu, janism@clemson.edu \\ Received October $28^{\text {th }}, 2009$; revised December $4^{\text {th }}, 2009$; accepted January $9^{\text {th }}, 2010$.
}

\begin{abstract}
The service sector is growing in importance in the US, particularly in B2B contexts. Despite this, research in these areas lags behind manufacturing and B2C studies. The purpose of this article is to begin addressing this issue by looking at how information technology can improve service delivery in B2B contexts by looking at the fit between the CSLC and a mix of customer contact technology modes. Specifically, we look at how Web 2.0 technologies facilitate interorganizational communication even for small and medium businesses by providing a wider variety of technologies at a lower cost. This allows businesses to use technology to reduce business customer uncertainty and equivocality, hence improving the quality of their service delivery. Due to the increasing use of the Internet as a source of communication and the evolution of customer expectations, this is becoming an increasingly important research topic. Propositions and implications are presented.
\end{abstract}

Keywords: Service Science, B2B, Customer Service Contact model, Customer Service Life Cycle, Media Richness Theory

\section{Introduction}

Although the service sector contributes $79.6 \%$ to the United States' GDP (Gross Domestic Product) [1], service research lags behind that of manufacturing. This is significant because the distinctive characteristics of managing services require a different approach than what is found in manufacturing [2]. IBM and others have recently urged participation in the service science movement (or Service Science, Management and Engineering - SSME). On their web page, IBM describes service science as "a growing multi-disciplinary research and academic effort that integrates aspects of established fields like computer science, operations research, engineering, management sciences, business strategy, social and cognitive sciences, and legal sciences" [3]. The goal of this movement is to improve quality and productivity, increase efficiency and scalability, and nourish learning and innovation rates in the service industry by combining interagency, interdisciplinary and innovative resources [3,4].

In addition to the shortage of research on the service industry, we also find that even though $85 \%$ of e-commerce is business-to-business (B2B) [5], most of the e-commerce research has been in business-to-consumer
(B2C) [6]. Just like the service science movement, researchers are calling for more research in B2B contexts [7]. This paper resides in that rare intersection of B2B service research and examines how technology, specifically Web 2.0 , can be used to facilitate efficient and effective service delivery.

To address this need, we bring together the customer service contact model [8] from the field of operations management, which describes various modes of customer contact, and the customer service life cycle model [9] from the field of management information systems, which describes the stages a customer must go through when contacting a vendor. Our intention is to bring insight to the question: "What form of information technology improves service delivery in specific situations?" To address the question, we created the matrix shown in Figure 1 (see Table 1 for construct definitions).

In this matrix, we cross Froehle and Roth's [8] technology-mediated customer service contact model with Ives and Mason's [9] customer service life cycle (CSLC) model. The technology-mediated customer service contact model indicates a range of service delivery modes ranging from technology-free, where two individuals conduct business without the aid of any technology, to 


\begin{tabular}{lcccc}
\hline $\begin{array}{c}\downarrow \text { Contact CSLC } \\
\text { Mode Stage } \rightarrow\end{array}$ & $\begin{array}{c}\text { Re- } \\
\text { quire- } \\
\text { ment }\end{array}$ & $\begin{array}{c}\text { Acqui- } \\
\text { sition }\end{array}$ & $\begin{array}{c}\text { Owner- } \\
\text { ship }\end{array}$ & $\begin{array}{c}\text { Retire- } \\
\text { ment }\end{array}$ \\
\hline Technology-Free & & & \\
Technoogy- & & & \\
Assisted & & \\
Technoogy- & & \\
Facilitated \\
Technoogy- \\
Mediated \\
*Peer-to-Peer \\
Technoogy- \\
Generated \\
*Technology-Only
\end{tabular}

*New contact modes added in this study to Froehle and Roth's framework [8]

Figure 1. Customer service contact mode / customer service life cycle matrix technology-only, where business transactions are conducted without the presence of any individuals. For the second dimension of our matrix, we chose to use Ives and Mason's [9] CSLC model because it provides a framework for applying IT to external, customer-focused applications [14]. The framework of their model contains four stages: requirements, acquisition, ownership, and retirement [9] as illustrated in the matrix. Specifically, this matrix links the way services are delivered to a business customer depending on the business customer's stage in the customer service life cycle. Our model will aid in the selection of the appropriate technology level based on the business customer's position within the customer service life cycle.

This paper contributes to the existing literature in the following ways. First, we present the matrix which provides strategic insight into which customer contact modes

Table 1. Construct definitions

\begin{tabular}{|c|c|}
\hline Construct & Definition \\
\hline Customer Contact & physical presence of the buyer in the service system [10] \\
\hline Full-Service & $\begin{array}{l}\text { the buyer interacts directly with the provider in the front office (e.g. technology-free and technology-assisted modes } \\
\text { of customer contact) [8] }\end{array}$ \\
\hline Self-Service & $\begin{array}{l}\text { the customer service representative does not actively participate in service performance (e.g. technology-generated } \\
\text { mode of customer contact) [8] }\end{array}$ \\
\hline Auto-Service & $\begin{array}{l}\text { no human involvement is required for business transactions to occur (e.g. technology-only mode of customer } \\
\text { contact) }\end{array}$ \\
\hline \multicolumn{2}{|r|}{ Mode of Customer Contact } \\
\hline Technology-Free & the buyer only makes contact with the service representative and technology is not involved at all in the process [8] \\
\hline $\begin{array}{l}\text { Technology- } \\
\text { Assisted }\end{array}$ & $\begin{array}{l}\text { the customer only makes contact with the service representative but the service representative has access to tech- } \\
\text { nology in order to process the transaction [8] }\end{array}$ \\
\hline $\begin{array}{l}\text { Technology- } \\
\text { Facilitated }\end{array}$ & the technology system available to both its service representatives as well as the service customer [8] \\
\hline $\begin{array}{l}\text { Technology- } \\
\text { Mediated }\end{array}$ & the service customer and service representative interact with technology but they do not interact with each other [8] \\
\hline Peer-to-Peer & the customers discuss (with other customers) the supplier's service on a supplier-provided platform \\
\hline $\begin{array}{l}\text { Technology- } \\
\text { Generated }\end{array}$ & the service customer interacts directly with the technology without the assistance of a service representative [8] \\
\hline $\begin{array}{l}\text { Technology-Only } \\
\text { Mode }\end{array}$ & the computer systems at both companies interact with each other with no human involvement \\
\hline
\end{tabular}

\section{Customer Service Life Cycle Opportunity}

\footnotetext{
Requirements analyze and define purchase requirements, gather service information from suppliers, and identify service providers that meet requirements $[9,11]$

Acquisition search for and identify potential suppliers, order the service, transfer funds, and evaluate the service [9,12,13]

Ownership integrate the service into business processes, monitor the interaction $[9,12]$

Retirement analyze expenses and switching costs [9,12]
} 
should be utilized at the various stages in the customer service life cycle. Second, we add two additional customer contact modes, peer-to-peer and technology only, to the work of Froehle and Roth [8]. Third, we provide insight into how Web 2.0 can be used for both intra- and inter-company coordination. Finally, we present research propositions based on our framework, leading to future research that can test our conceptual framework.

This paper is organized as follows. In the next section we provide a background on Web 2.0, the characteristics of business-to-business transactions, and the concepts of equivocality and information richness. The succeeding section presents our model and propositions. The final section discusses implications for future research.

\section{Background}

In this section we provide information which will set the stage for the presentation of our model in Section 3. Our first background section covers Web 2.0, followed by a section on B2B, and finishes with a discussion of equivocality and information richness.

\subsection{Web 2.0}

Because Web 2.0 is a fairly new technology, we will define Web 2.0, describe four concepts of Web 2.0 that are suitable for B2B usage, and discuss how businesses can exploit these concepts for their B2B transactions. First, we define Web 2.0 as a collection of websites that use information technologies and applications to encourage user participation, information sharing, social interaction, and collaboration [5]. Unlike the more traditional websites (referred to as Web 1.0), Web 2.0 sites are typically used as services to accomplish tasks, typically with other people [5]. In a B2B context, companies can leverage Web 2.0 concepts such as Rich Internet Applications, Software-as-a-Service, collective intelligence, and mashups [15]. These are described in detail in the following paragraphs.

The first Web 2.0 concept that applies to B2B environments is Rich Internet Applications (RIA). These applications allow business customers to specify the type of information they want to receive from a supplier so that the supplier can proactively provide the information [15] and the buyer can then organize and view the information they receive more effectively [16]. For example, Web 2.0 can enable a business customer to automatically and securely access information about their account or perform complex data entry for highly customized purchase orders through an easy-to-use desktop-like experience such as drag and drop [17,18]. In short, Web 2.0 technology allows a business customer to get real-time information about their account or current business transactions in an information-rich environment with the added benefit of being able to do it from anywhere at any time [17]. This results in improved responsiveness and operational effi- ciency on the part of the supplier [15,19].

Second, Web 2.0 delivers functionality as a service rather than packaged software [5]. The B2B concept is Software-as-a-Service or SaaS. This means instead of purchasing software to install on company computers, a supply chain member can access the software, and all of the relevant data, through the internet by use of a web browser (and the correct password) from any location at any time. Since the software is not purchased and installed, payment to the software supplier is commonly pay-per-use. Also because the software and data are not installed on local computers, updates and maintenance are transparent to end-users, allowing software suppliers to continuously update the software and users to have access to the latest version of the software [15].

A third, applicable concept for B2B contexts is that Web 2.0 is based on collective intelligence (a group of people can both contribute to and use the information gathered). One of the best examples of collective intelligence, although not $\mathrm{B} 2 \mathrm{~B}$ or even business-related, is Wikipedia, as it supports more than 1.5 million articles written completely by user contributions. Another form of this collective intelligence is blogs where users post their solutions to problems they have personally encountered, or respond to requests to solve the problems of others [5]. In a B2B environment, collective intelligence can be used to improve forecasts or understand demand patterns. Additionally, customers can exchange their views on the supplier's service [15-20] or share ideas on how to improve the service [18]. Several of the top Enterprise Resource Planning (ERP) software vendors support blogs where experienced users can discuss issues encountered in using the ERP applications as well as the solutions they arrived at to address the issues. As these systems attract more user participation, they will become even more valuable, unique, and richer [18]. And when users help each other, the supplier doesn't have the expense of providing quite as much customer support.

The fourth and final Web 2.0 concept is the support of mashups. A mashup is the result of the transformation that occurs when local data is integrated with one of several powerful web services such as Google Maps [15]. For example, it is possible to analyze local firm data about the location of supply chain members and/or shipments by combining it with the Google Maps' application to get a visual display of the routes of all shipments to and from a plant. Viewing data in new ways may enable supply chain efficiencies, such as sharing transport or minimizing deadhead miles, which can benefit the entire supply chain.

So how can businesses exploit these concepts in their B2B transactions? Many small businesses have hesitated to invest in interorganizational systems, such as electronic data interchange (EDI), in the past [21-23] due to resource constraints and failure to understand the strate- 
gic benefits of these types of systems [24,25]. In addition, the negative repercussions of investing in these systems can be major [22]. Typically, small and medium businesses are more likely to adopt these systems because of external pressures such as competitive pressure, dependence on trading partner, trading partner pressure, or industry pressure $[21,23]$. However, Web 2.0 technologies provide low-cost options for smaller businesses. In fact, small businesses may be able to integrate Web 2.0 technologies before many of the larger businesses, because the large businesses are tied to their legacy systems [26]. This likely explains why Forrester Research Inc. predicts investments in Web 2.0 technologies will increase an estimated $43 \%$ per year over the next 5 years with a total of 4.6 billion investment dollars being spent on the technology by 2013 [27].

\subsection{Business-to-Business}

Parasuraman and Zinkhan [7] wrote in a special issue of the Journal of the Academy of Marketing Science that most of the scholarly research has been focused on B2C even though the internet affects both B2C and B2B and the "economic magnitude of $\mathrm{B} 2 \mathrm{~B}$ transactions are estimated to be substantially higher than that of B2C transactions" (p292). They conclude there is "clearly a need for more research in B2B contexts" (p293). LaPlaca and Katrichis [6] give two reasons for the imbalance of B2B and $\mathrm{B} 2 \mathrm{C}$ articles in the marketing literature. The first reason is $\mathrm{B} 2 \mathrm{C}$ data is more available than $\mathrm{B} 2 \mathrm{~B}$ data. The second is that consumer marketing is more popular than business marketing among students.

When compared to $\mathrm{B} 2 \mathrm{C}$ relationships, developing effective B2B relationships through the use of technology has the potential to significantly benefit all members of a supply chain. Within a long supply chain (as illustrated in Figure 2), all but one of the transactions occur between businesses. The only transaction that involves the customer is the final transaction in the chain. In lean supply chains, businesses actively strive to establish long-term relationships with a small number of suppliers $[28,29]$. This makes it worthwhile and economically feasible for both business suppliers and business customers to invest the required money, time, and effort needed to automate their supply chain relationships [30]. In addition, the long history of EDI has demonstrated that many B2B transactions are fairly standard, making them amenable to automation [31].

\subsection{Equivocality and Information Richness}

Daft and Lengel [32] discussed why organizations gather and process information and conclude that "information is processed to accomplish internal tasks, to coordinate diverse activities, and to interpret the external environment" (p555). They further state that, in order to accomplish these goals, organizations must overcome both un- certainty and equivocality. They defined uncertainty as the absence of information. To reduce uncertainty, the organization gathers information that is assumed to exist. When enough information is obtained, a clear decision can be made.

Equivocality is similar to uncertainty, but it presumes ambiguity. This means even if a plethora of data is obtained, it could still result in multiple, conflicting interpretations and an unclear solution [32]. Daft and MacIntosh [33] used the term "unanalyzability" to describe a similar concept. In order to reduce equivocality, managers cannot just collect more data; instead, they must ponder the issue at length, use judgment coming from experience, and elicit discussions with those of both similar and opposing views. So the solution to equivocality is what Daft and Lengel [32] call rich information. They define information richness as "the ability of information to change understanding within a time interval. Communication transactions that can overcome different frames of reference or clarify ambiguous issues to change understanding in a timely manner are considered rich. Communications that require a long time to enable understanding or that cannot overcome different perspectives are lower in richness" (p560).

Daft, Lengel and Trevino [34] further the discussion of information richness and identify four characteristics of rich media, which they define as media which has the capacity to process rich information. Their first characteristic of rich media is that it provides immediate feedback to both the message sender and the message receiver so they can check interpretations without delay. The second characteristic of rich media is it provides multiple cues which the message receiver is able to infer information not explicitly stated in the message (e.g. tone of voice and body language). Their third characteristic of rich media is it is able to convey material in a variety of formats such as pictures, symbols and verbal statements. They call this characteristic language variety. Their fourth and final characteristic of rich media is that rich messages can be tailored with a personal focus so that it fits personal circumstances and can be infused with emotions and personal feelings. They then go on to order media from most rich (face-to-face) to least rich (impersonal, written documents). Daft et al. [34] also found that managers who could recognize the equivocality of a message and then chose appropriate media to convey the message (media high in richness to convey highequivocality messages and media low in richness to convey low-equivocality messages), had higher performance ratings than managers who were unable to match the media to the equivocality of the message.

In this paper, we intend to illustrate that the stages in the customer service life cycle [9] vary in equivocality, and that the modes of customer contact [8] vary in media 
richness, allowing us to recommend appropriate customer contact modes for different stages in the customer life cycle.

\section{Research Model}

In this section we present the details of our model first introduced as Figure 1. We will first discuss the mode of customer contact (rows) followed by the stages in the customer service life cycle (columns).

\subsection{The Mode of Customer Contact Dimension}

To address the different customer contact technology modes, we will utilize Froehle and Roth's [8] model of conceptual archetypes of customer contact in relation to technology, and describe how they vary in the B2B context. We will first provide an overview of this model and describe each customer contact mode. Then, we will discuss how each type of contact (full-, self-, or auto-service) can be addressed by different levels of media richness according to Media Richness Theory. We will present propositions for each type of contact.

Figure 3 illustrates the broad range of conceptual archetypes (or technology modes) of customer contact. They can range from traditional, technology-free services to completely automated e-services ("comprised of all interactive services that are delivered on the Internet using advanced telecommunications, information, and multimedia technologies" [35 p175]). According to Froehle and Roth [8], the first type of contact, technology-free customer contact (Figure 3A), occurs when the business customer only makes contact with the service representative and technology is not involved at all in the process. A second form of contact, technology-assisted customer

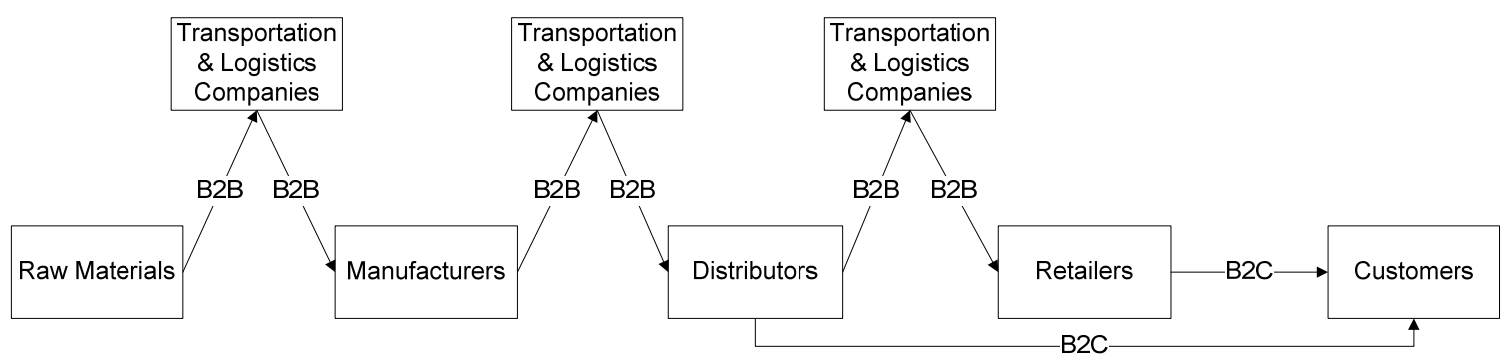

Figure 2. Example of a supply chain [Adapted from PowerPoint slides of 5]
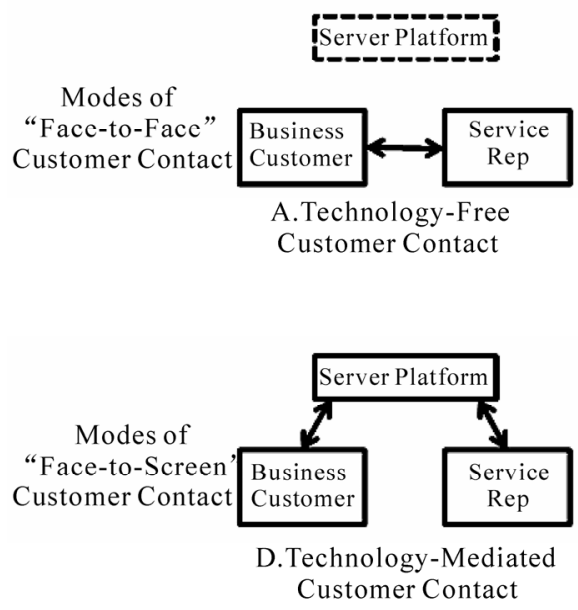

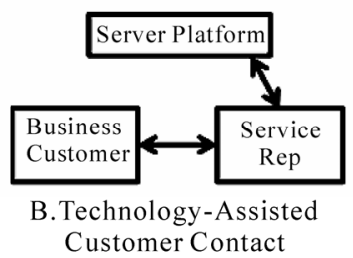

Customer Contact
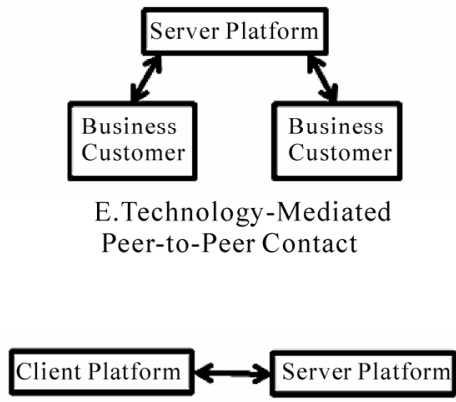

Modes of "Screen-to-Screen" Customer Contact

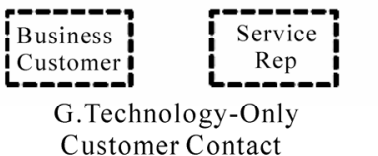

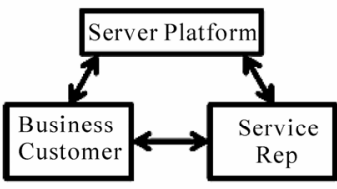

C.Technology-

Facilitated Customer Contact

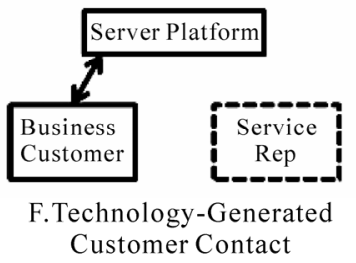

Figure 3. Froehle and Roth's [8] customer contact technology modes with B2B marketplace adaptations for S2S and P2P 
contact (Figure 3B), occurs when the business customer makes contact with the service representative and the service representative makes use of technology (such as Web 2.0 technologies like wikis or blogs) in order to serve the business customer. These two types of customer contact are referred to as full-service contacts. A third form of contact, technology-facilitated customer contact (Figure 3C), occurs when a supplier makes the technology system available to both its service representative and its business customer. In addition to interacting with the system, the service representative and business customer also interact directly with each other. All three of these customer contact models (Figures 3A, 3B, and $3 \mathrm{C})$ are considered "face-to-face" solutions to customer service.

"Face-to-screen" contact occurs, also according to Froehle and Roth [8], when the business customer interacts only with technology and not with the service representative. The first "face-to-screen" mode is technology-mediated customer contact (Figure 3D) where both the business customer and service representative interact with technology but they do not interact directly with each other. In technology-generated customer contact (Figure 3F), the business customer interacts directly with the technology without the assistance of a service representative; therefore, Froehle and Roth [8] considered this self-service contact.

One additional form of self-service interaction for business customers not mentioned by Froehle and Roth [8] is as a member of a virtual community where a buyer can interact with other buyers in lieu of a service representative (Figure 3E). An example of this is the "collective intelligence" Web 2.0 concept. In this case, business customers can interact directly with each other on a site provided by the supplier (e.g. http://blogs.oracle.com/) [36]. Businesses can install platforms to facilitate peer-to-peer interactions that can be used to solve and share solutions to mutual problems related to the company's service $[17,18,20]$. This interaction can be of two distinct types: viewing and posting. Customers can view (read) comments written by other customers or post (write) their own comments or questions that can be viewed by others. We call this technology-mediated peer-to-peer (P2P) contact.

These six technology-mediated customer contact modes can apply to both B2C and B2B marketplaces because a company's buyer can have the same type of relationship with a service supplier as an individual consumer can. However, B2B marketplaces, effectively, have an additional mode we call technology-only cus-

\footnotetext{
${ }^{1}$ While it could be argued that personal, automatic payments could be an example of $\mathrm{B} 2 \mathrm{C}$ technology-only customer contact, we argue this type of contact is actually B2B since the automatic payments are processed by either a bank or credit card company. Therefore, this type of interaction is ultimately B2B even though it seems B2C from the consumer's point of view.
}

tomer contact (Figure $3 \mathrm{G})^{1}$. In this scenario, the technology systems at both the buyer's and supplier's companies interact with each other with no human involvement. For example, organizations have deployed inter-organizational B2B applications such as purchase order processing, invoice and payment processing, and procurement analysis [37]. Since this is not face-to-face or face-toscreen, so we call this auto-service contact.

\subsubsection{Full-Service (Figures 3A and 3B)}

There are three main benefits for the business customer in full-service customer contact modes. First, the buyer receives high human contact. This is important because, according to Vickery et al. [38], rich information "should be particularly relevant to customer contact in an industrial service environment" (p1108). The two media channels with the highest information richness include face-to-face and the telephone [32,34,38]. Only the full-service offers this type of human interaction because all the other modes involve the business customer interacting with a computer. A second benefit is most or all of the risk is the responsibility of the server. This assumption of risk can be critical for those customers who are inclined toward full-service [39]. Full-service gives these buyers the opportunity to avoid any risk in the performance of the service because the server is accountable for all of the activities after the intent to purchase is stated [39-41]. The final benefit of full-service contact is an avoidance of customer effort. Just like risk, the burden of activity resides with the server. This is particularly important for "non-standard" transactions [35] such as configuring specialized, industrial electric motors. Because the configuration can significantly influence the reliability of the motor [42], it requires a knowledgeable individual. If the buyer simply places the order, the burden of proper configuration is placed on the supplier [39].

Proposition 1: Business customers who need rich information, are risk-averse, and want to avoid extra effort will be more likely to opt for full-service contact with their suppliers, if given a choice.

\subsubsection{Self-Service (Figure 3F)}

In this type of service offering, the service representative does not actively participate in service performance. These types of interactions are called Self-Service Technologies (SSTs) [8]. SSTs are defined as the "technological interface that allows customers to produce and consume services without direct assistance from employees" [43 p283]. For example, employees at General Electric (GE) use a system called Trading Partner Network Register to electronically order office supplies from pre-approved vendors because it saves them money [44], wait times are shorter, no paperwork needs to be filled out, and authorizations are done electronically $[41,45]$. In addition to these benefits, SSTs offer an interactive, convenient, consistent, and personal way of communi- 
cating with the seller $[35,41,46]$. While SSTs can provide immediate feedback and a personal focus, they do not offer the same number of cues (e.g. body language and tone are not conveyed) or language variety (e.g. verbal statements combined with pictures or graphs); therefore, they are considered less rich [34].

For the supplier, SSTs can also offer a number of benefits. First, they can reduce costs [47] by eliminating costly specialists and experts [35]. Second, they allow the organization to meet customer demand for alternative ways of purchasing services. Third, SSTs can allow a company to generate new markets by introducing a new channel that will reach worldwide markets [47].

It is important to note all of these benefits are not automatic or all-encompassing. First, the supplier must analyze its buyers' wants, needs, and capabilities to determine if self-service is the appropriate offering $[48,49]$. For example, the supplier needs to determine whether the customer willing to accept the lack of verbal communication inherent in less media rich channels [34]. Second, if SSTs are appropriate, the supplier has to try to customize the web interface to meet specific buyer needs. This typically results in a more complex website because of the level of personalization that is required. However, the website must still be simple, accessible, easy to use $[35,41]$ and provide immediate feedback through pictures, on-screen displays, or text messages.

Proposition 2: Business customers who do not require verbal cues or statements (i.e. less rich information) will be more likely to opt for self-service contact with their suppliers, if given a choice.

\subsubsection{Auto-service (Figure 3G)}

Auto-service customer contact solutions are at the extreme of technology-mediated customer contact solutions. In this scenario, no human involvement is required from either supplier or customer for the business transactions to occur. In other words, the buyer and supplier work together to create a shared infrastructure utilizing the Internet and other technologies as a means for commercial exchange. These systems are referred to as interorganizational information systems [50,51]. A traditional example is Electronic Data Interchange (EDI) [49]. EDI is a standard protocol for electronically exchanging documents like purchase orders, invoices, and advanced ship notices. In the past, data was converted using expensive translation software and exchanged between corporations through a Value-Added Network (VAN) or a Virtual Private Network (VPN). Since it was so expensive and complicated, implementation of these types of technologies was usually restricted to large businesses [52]. If small businesses did choose to use interorganizational systems, they did so in response to competitive, trading partner, or industry pressure [21,23]. However, Web 2.0 technologies like enterprise application integra- tion (EAI), Internet-based EDI, and point-to-point or system-to-system has made "auto-service" modes of customer contact available to even small and medium firms since these technologies are services rather than software packages that need to be purchased [15].

The main benefit of these auto-services is they allow firms to exchange information quickly [38] and more frequently because their systems are linked together [53]. Some other benefits of this technology include reducing transaction costs, reducing order cycles, improving partner relationships, improving the flow of data, and improving planning and forecasting [54].

Just like full- and self-service, auto-service does have disadvantages. For example, electronic media, like EDI, are considered "lean" or less rich $[38,53]$. Electronic media receive this label because the channel restricts visual communication [38]. Another disadvantage of autoservice is the substantial coordination costs necessary to connect the two systems [21]. However, Web 2.0 promises to reduce those costs because it can be used as a service (e.g. SaaS) or the software can be hosted either by the supplier or by a third-party host, so we propose:

Proposition 3: As Web 2.0 becomes more widely accepted, supplier companies will be able to provide richer information to their customers at a lower cost, so they are more likely to use Web 2.0 technologies than traditional interorganizational systems like EDI.

\subsubsection{Mode Combination (Figures 3C and 3D)}

As shown in Figure 3, there are middle-ground options available to sellers. First, the company can make their technology available to both the service representative and the service customer in a technology-facilitated customer contact. Second, the organization can support a technology-mediated customer contact environment where both the customer and representative mutually interact with the technology but not directly with each other [55]. These combined with full-service, self-service, and auto-service offer a wide variety of options that can be mixed-and-matched to best meet the customer's needs.

There are other ways that a company can utilize various modes of customer contact. One example of this combination is a company that provides full-service on the first transaction in order to demonstrate usage of the system while subsequent transactions are performed by the customer in self-service mode. A company could also split its high-volume, standardized services from its low-volume, customized services. The supplier could make its high-volume, standardized services available on their website while the customized services are handled by full-service customer representatives. Therefore, the business customer receives the benefit of both rich and lean media depending on the circumstance. In summary, the business customer can employ "media switching" 
based on the task at hand [56].

Proposition 4: Business customers will use a variety of contact modes depending on the previous number of transactions or the type of transaction.

\subsection{The Customer Service Life Cycle Dimension}

To address the different customer life cycle dimensions, we will utilize Ives and Mason's [9] model of the customer service life cycle. As illustrated in Figure 4, there are four stages in this life cycle. The first stage of the customer life cycle is the requirements stage. This stage presents the supplier with a number of opportunities for serving the customer more effectively with technologies such as Web 2.0. For example, suppliers can develop websites specifically designed to provide customers with the information they need (e.g. inventory levels, tracking information). These websites can offer real-time information (i.e. immediate feedback). They can also specifically address services the business customer is interested in purchasing (e.g. personal focus) and present the information in multiple locations (e.g. a service could be viewed through the supplier's website or an offsite blog ${ }^{2}$ ) and multiple ways (e.g. language variety through demonstrations, trial packages, or written descriptions of the service). In other words, the supplier can use the Internet to provide a greater richness of information $[8,57]$ that is unconfined by individual salespeople having to contact the customer during normal business hours $[58,59]$.

In addition, the data can be more comprehensive, including both service details and specifications as well as potential application suggestions [58]. Since most organizations are utilizing their websites to provide more comprehensive information [13], the buyer can easily become overwhelmed by the sheer volume of options available to him and his company for purchasing services [60]. This is combined with the fact the buyer may already be addressing an ambiguous business need, particularly when it comes to the nature of services [61]. In order to deal with the complexity, uncertainty, equivocality, and information overload introduced by technology-mediated marketplaces $[11,62,63]$, suppliers need to be proactive about providing service recommendations or substitution queries that help buyers filter unwanted services and alleviate some of the confusion and information-overload problems.

The second stage in Ives and Mason's [9] CSLC is the acquisition stage. In this stage, the buyer first searches

\footnotetext{
${ }^{2}$ SAP is a notable example of this. Not only does SAP provide an "SAP Community" for its business customers on its website (see http://sap. ittoolbox.com/), but they also have a separate blog site (http://sapro. blogspot.com/). Through these two sites, SAP customers can request weekly newsletters, e-mail alerts, and join groups. They have access to blogs, wikis, white papers, and other resources. In the blogs, SAP employees, SAP consultants, and SAP customers discuss their implementation challenges, the issues they experience using the SAP software, and how they overcome the problems they face with SAP.
}

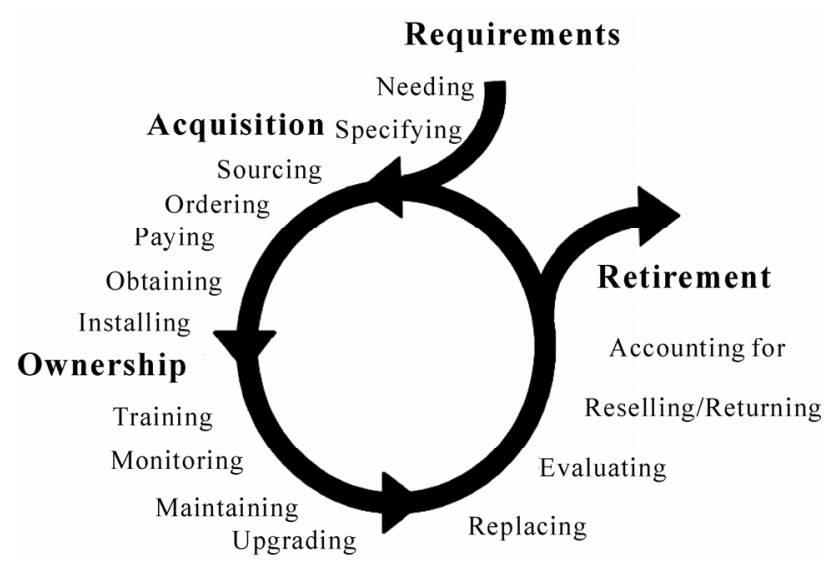

Figure 4. Ives and Mason's customer service life cycle [9]

for and identifies potential suppliers for the services identified in the requirements stage [64]. Through Web 2.0-supported peer-to-peer sites, the buyer can gather information from those who have provided comments about the service. Once a procurement source has been chosen, the buyer orders the service from the supplier [12]. The buyer then has the option to follow the progress of the order [13]. Once the order arrives and the buyer takes possession, he can transfer the appropriate funds $[12,65]$. Finally, the buyer can perform a service evaluation [13] to ensure the service meets expectations [12]. Unlike the first stage, this stage has a lower level of equivocality since there are a finite number of suppliers available.

The third stage in Ives and Mason's [9] CSLC is the ownership stage. This stage involves integration with other services, monitoring the access and use of the service, and upgrading to higher levels of service as needed to meet changing requirements $[12,14]$. As more companies refocus their efforts on core competencies, this stage can also include pay-for-usage models typical of outsourced activities [58]. This stage has an even lower level of ambiguity than the previous two stages because the company is likely going to have well-defined purposes for the purchased service. The only equivocality at this stage is the dyadic choice of upgrading to higher levels of service or not.

Finally, the buyer enters the fourth stage in Ives and Mason's [9] CSLC - retirement. This encompasses the analysis of expenses and the transfer or cancellation of the service [12]. At this stage, the buyer and supplier have the opportunity to establish a relationship instead of continuing to search for new partners that satisfy their service needs [66]. Business customers in this stage demonstrate the lowest level of equivocality because they only have to choose between continuing with the current supplier and moving to another supplier. If they choose to select a new supplier, they would move back into the requirements stage with its highest level of equivocality. 
While the model proposed by Ives and their model is $\mathrm{B} 2 \mathrm{C}$ in nature, it can be modified to reflect the needs of B2B buyers. Unlike B2C marketplaces, B2B buying situations typically involve different decision-makers along the life cycle. This means the person who makes decisions in the requirements stage may be different from the person who actually purchases the service in the acquisition stage [67].

\subsection{Mode of Customer Contact / CSLS matrix}

With the two dimensions defined, the complete matrix shown in Figure 1 is considered. From the supplier's perspective, moving from the top to the bottom of the table reduces labor requirements. The top four rows (technology-free, -assisted, -facilitated, and -mediated) require service representative to interact with the business customer at some level. The bottom three rows, on the other hand, don't require interaction with any employee (peer-to-peer, technology-generated, and technology-only). From the business customer's perspective, the upper three rows of the table involve face-to-face interaction with a service representative, the next three rows are self-service in which the business customer is required to interact with the technology, and the final row does not require any interaction by either party.

By analyzing each stage in the customer service life cycle, a service-provider can identify opportunities for appropriate customer contact technology modes and avoid excessive IT spending that might result in unnecessary technology and potential buyer loss. Full-service customer contacts give customers human contact and risk-free service activities. Self-service technologies, on the other hand, offer customers control, convenience, and consistency across their service experience. By analyzing the customer's needs/wants and the service provider's technological ability, the company can offer the appropriate service for each circumstance.

We posit that levels of equivocality decrease when moving from left to right in the matrix. The most ambiguous phase is the requirements phase which has a higher level of equivocality than the acquisition phase which has higher levels than the ownership phase which has higher levels than the retirement phase. As the customer moves through the service process life cycle, from left to right in our matrix, from requirements, to acquisition, to ownership to retirement, the transactions become more routine and require fewer customer contact modes and less media richness and are more suitable for automating.

We also posit that media richness decreases when moving from top to bottom of the matrix. Technology-

\footnotetext{
${ }^{3}$ Repeat customers move directly from the retirement phase to the acquisition phase without cycling through the requirements phase, so only new and inexperienced customers enter the customer service life cycle through the requirements stage.
}

free, or full-service, is the richest mode of customer contact because the business customer and service represent interact directly via face-to-face or telephone conversations which are not constrained by any technology. Moving down through the rows of the matrix, contact with the service provider decreases and contact with technology increases. As the technology contact increases, this indicates a move toward less-rich media characterized by limited visual channels of communication [38]. The seventh row, auto-service, needs to be extremely structured so that the transaction can occur without intervention from the service representative.

As equivocality decreases right to left and media richness decreases top to bottom, we suggest the most appropriate matching of customer contact with stages of the customer life cycle will appear in a broad diagonal band going from the upper left to lower right. Because not every task in each stage of the customer life cycle has the same equivocality, it is possible to effectively use almost every mode of customer contact in every stage of the life cycle (see Table 2). For example, even if the two companies have an EDI-type relationship, it may be necessary to resort to technology-free face-to-face communication in order to solve a specific problem [53]. Additionally, it is possible a business customer in the requirements phase may want to peruse the comments in an online community discussion or download detailed specifications, resulting in effective off-diagonal positions. We now go on to discuss the diagonal positions and generate propositions for each stage.

\subsubsection{Requirements}

The requirements phase, the leftmost column in the matrix, is the time during which the new business customer moves from first realizing a need exists to specifying the attributes that will meet that need ${ }^{3}$. During this stage, the supplier company needs to educate potential business customers about the purpose of their service and help these business customers distinguish their service from the services of their competitors [68].

The decisions made in this stage have high levels of equivocality because gathering more data can easily result in more interpretations of the data, especially for services of which the buyer does not have experience. Because of the high levels of equivocality in this phase, a company should provide customers with as many contact modes as possible, including fact-to-face options, in order to make the communication with the potential customer as rich as possible. Therefore, we propose:

Proposition 5: In the CSLC requirements stage, customers will experience the highest levels of equivocality.

Proposition 6: In the CSLC requirements stage, rich media will be utilized to assist the customer to manage high levels of equivocality. 
Table 2. A matrix for linking CSLC opportunities and customer contact technology modes

Customer-Service Life Cycle Stage

\begin{tabular}{|c|c|c|c|c|c|}
\hline & & Requirements & Acquisition & Ownership & Retirement \\
\hline \multirow{7}{*}{ } & Technology-Free & $\begin{array}{l}\text { - presales support and service } \\
\text { specialists for high-demand } \\
\text { customers [69] } \\
\text {. understand the buyer's } \\
\text { problem and seek solutions } \\
\text { to it [58] }\end{array}$ & $\begin{array}{l}\text { "non-standard" transac- } \\
\text { tions [35] } \\
\cdot \text { sales force to maintain } \\
\text { public relations [10] } \\
\cdot \text { request for information } \\
\text { (RFI) service - written } \\
\text { information about the } \\
\text { capabilities of various } \\
\text { suppliers [64] }\end{array}$ & & \\
\hline & Technology-Assisted & $\begin{array}{l}\text { - single-point sales contact - } \\
\text { he utilizes technology to } \\
\text { maintain the vast amount of } \\
\text { service information [58] }\end{array}$ & $\begin{array}{l}\text { automate quote genera- } \\
\text { tion and order tracking for } \\
\text { the sales force [78] }\end{array}$ & & \\
\hline & Technology-Facilitated & $\begin{array}{l}\cdot \text { marketing/advertising tool } \\
{[13]}\end{array}$ & $\begin{array}{l}\cdot \text { customer service call } \\
\text { center applications - rout- } \\
\text { ing, queue management } \\
{[78]} \\
\cdot \text { transactional interaction } \\
\text { (e.g. order entry, delivery, } \\
\text { order } \\
{[57,65,69,79]}\end{array}$ & $\begin{array}{l}\text { routine ques- } \\
\text { tions via elec- } \\
\text { tronic interaction; } \\
\text { complex prob- } \\
\text { lems via live } \\
\text { interactions [69] }\end{array}$ & \\
\hline & Technology-Mediated & $\begin{array}{l}\text { contact sales staff through } \\
\text { the website }[13]\end{array}$ & $\begin{array}{l}\text { purchase on-line, pick-up } \\
\text { in person [59] } \\
\text { - pay for orders online [13] }\end{array}$ & $\begin{array}{l}\quad \text { management } \\
\text { information and } \\
\text { reporting [48] } \\
\cdot \text { online support } \\
{[13]}\end{array}$ & \\
\hline & Peer-to-Peer & $\begin{array}{l}\text { research/verify the experi- } \\
\text { ences of existing customers } \\
{[17]}\end{array}$ & & $\begin{array}{l}\text { problem resolu- } \\
\text { tion through } \\
\text { interactions with } \\
\text { customers en- } \\
\text { countering simi- } \\
\text { lar problems [18] }\end{array}$ & \\
\hline & Technology-Generated & $\begin{array}{l}\cdot \text { service catalogues }[11,57, \\
65,71,79] \\
\cdot \text { automated caller ID units } \\
\text { and voice response units that } \\
\text { suggest solutions to meet } \\
\text { needs }[58] \\
\cdot \text { customer forums [58] }\end{array}$ & $\begin{array}{l}\text { service and pricing trans- } \\
\text { parency real-time }[59,88] \\
\cdot \text { global marketing auto- } \\
\text { mation - segmentation, } \\
\text { targeting, response track- } \\
\text { ing }[59,78] \\
\cdot \text { personalized purchasing } \\
\text { website }[69] \\
\cdot \text { order tracking }[13]\end{array}$ & & $\begin{array}{l}\text { receive auto- } \\
\text { matic, real-time } \\
\text { information about } \\
\text { the supplier's } \\
\text { inventory levels to } \\
\text { make restock } \\
\text { decisions or adjust } \\
\text { forecasts [15] }\end{array}$ \\
\hline & Technology-Only & & $\begin{array}{l}\cdot \text { EDI } \\
\cdot \text { automated payment sys- } \\
\text { tems [71] }\end{array}$ & $\begin{array}{l}\cdot \text { automate cur- } \\
\text { rent information } \\
\text { flows }[35,49,83]\end{array}$ & \\
\hline
\end{tabular}


As illustrated in Table 2, research has shown that suppliers do employ a wide spectrum of customer contact technology modes to handle the complexity of the service being sought or the depth of information that must be gathered in order to suit many different buyer needs. For example, high-demand customers might need faceto-face presales support to handle all their specific service questions [69]. On the other hand, some buyers might have some generic questions that can be resolved by automated caller ID units that ascertain customer needs and then make suggestions without direct contact with a salesperson [58]. Another possibility is these issues could be resolved by the business customers themselves by accessing comments from an online users' community that can be used to determine attributes of actual service usage as well as company responsiveness issues [18]. Since different buyers will have different levels and timing of customer demand [70], a single technology-mediated service is not sufficient. Therefore, we propose the following:

Proposition 7: All modes of customer contact except auto-service will be commonly utilized in the requirements stage.

Proposition 8: Peer-to-peer contact will be dominated by viewing, with little or no posting.

\subsubsection{Acquisition}

Customers can enter the acquisition stage from the requirements phase or from the retirement phase of a previous order cycle ${ }^{3}$. Customers who are entering from the requirements phase experience a lower level of equivocality than they did in the first stage because now the supplier choice has been limited to those that offer the required services. On the other hand, customers entering from the retirement phase do not experience any equivocality because they've already done business with the supplier, so they know what to expect. Therefore, we propose:

Proposition 9: In the CSLC acquisition stage, equivocality will be lower than it was in the requirements phase.

Proposition 9a: In the CSCL acquisition stage, new customers will experience high levels of equivocality.

Proposition 9b: In the CSCL acquisition stage, customers retiring previous services with the same supplier will experience low levels of equivocality.

Just like the requirements stage, the acquisition stage presents a number of opportunities for the supplier to support the buyer through a mix of customer contact technology modes. First, this stage presents opportunities for automated payment systems [71]. For example, buyers and suppliers can exchange invoices via EDI or utilize automated clearinghouse $(\mathrm{ACH})$ transactions. These systems allow the two parties to bundle transactions and avoid manual entry and reconciliation. Therefore, they can reduce or eliminate financial and human resources personnel for those processes [72]. Another opportunity is the supplier can make sure its website has clear and accurate pricing information [73,74]. This presents at least two benefits for both the buyer and the supplier. The first benefit is the buyer's uncertainty about the transaction process is reduced because the pricing information is readily available. This makes the buyer more likely to purchase from the supplier and it reduces the coordination costs of the transaction for both parties [75]. A second benefit is the price-sensitive buyer can accurately weigh the supplier against potential competitors [76]. Once the buyer chooses a supplier, he might be willing to establish a collaborative relationship with the supplier. This would mean the two parties could improve their efficiency as they synchronize their planning and scheduling activities [46,65]. Finally, the supplier can offer financial services or logistics arrangements in order to facilitate the order process $[65,66]$. Providing financial services, for instance, gives the buyer access to real-time payments or credit approvals [65] that can speed-up the order entry process for buyers. Since research indicates buyers are reducing their number of suppliers [77], any opportunity the supplier can find and meet will give that supplier an advantage.

As illustrated in Table 2, different customer contact technology modes provide a wide range of ways to fulfill these needs. For example, the supplier can empower its sales force by creating automatic systems that generate quotes and orders, provide contact management tools, and facilitate pipeline management [78]. Armed with this information, these salespeople can quickly and flexibly respond to the buyer just like the buyer wants [59]. For technology-facilitated services, the supplier can provide transactional interactions that allow the buyer to perform his own order entry or order tracking via the website $[57,65,69,79]$. This gives the buyer another valuable channel [80] for meeting his needs consistently and accurately [74]. In addition, interaction with an online users' community can assist with installation and early usage issues [18]. Because we can address the acquisition opportunities with a wide spectrum of customer contact technology modes, we propose:

Proposition 10: All modes of customer contact will be commonly utilized in the acquisition stage, but the use of self-service and auto-service will be higher than in the requirements stage.

Proposition 11: Peer-to-peer contact will be primarily viewing, with some posting.

\subsubsection{Ownership}

Typically, the supplier's role is to provide basic training [69] or education about the benefits of the service. Routine, unambiguous questions can be addressed electronically (e.g. FAQ sections on the supplier website) 
while the more complex, equivocal problems can be handle via live interactions (e.g. demonstrations over the phone or through a salesperson visit) [69]. Customers can leverage online users' communities to solve unique problems and to find innovative uses for the service [18]. Since this stage doesn't require the interaction-intensity of the previous two stages [71], we propose the following:

Proposition 12: In the CSLC ownership stage, customers will experience lower levels of equivocality than in the acquisition stage.

Proposition 13: In the CSLC ownership stage, the use of self-service customer contact modes will increase and the use of full-service customer contact modes will decrease when compared to their use in the acquisition stage.

Proposition 14: Peer-to-peer contact will be both viewing and posting.

\subsubsection{Retirement}

Firms can establish their value-added partnership by automating their current, standardized/unambiguous, information flows through interorganizational systems like EDI [49]. This means firms can coordinate their simple processes (e.g. inventory management) $[81,82]$ or automate their high-volume, repetitive restocks $[35,49$, $83,84]$. As the services become more standardized, local knowledge and relationships become less crucial [85]. Therefore, the supplier and buyer can utilize different modes of technology services in order to reduce their coordination costs. In addition, as customers gain more experience with the service, they will become more active in participating in online users' communities because they will be able to offer suggestions of their own related to the service $[15,20]$. Therefore, we propose the following:

Proposition 15: In the CSLC retirement stage, customers will experience the lowest levels of equivocality.

Proposition 16: In the CSLC retirement stage, the use of self-service customer contact modes will increase and the use of full-service customer contact modes will decrease when compared to their use in the ownership stage.

Proposition 17: Peer-to-peer contact will be primarily posting, with some viewing.

\section{Implications and Conclusions}

In future research, scholars should explicitly examine the relationship between each CSLC opportunity and the mix of implemented customer contact technology modes. By using the customer as a unit of analysis, researchers can identify how different customers respond to different service offerings. In these studies, it will be important to control for different supplier sizes because they adopt B2B portals to different degrees. For example, smaller suppliers are less likely to create B2B websites because they are expensive and are likely to have fewer customers that will utilize these sites [86]. However, smaller suppliers are more likely to establish these types of sites in the future as Web 2.0 becomes more common. Larger suppliers, on the other hand, have access to more financial resources as well as in-house expertise so they find it easier to adopt B2B portals [52].

It would also be beneficial to study each technology-mediated service as a different variable. Future researchers could compare service experiences for each model to determine if one model is preferred over another in B2B marketplaces. Again, it is important to control for supplier size to determine if resource expenditures are the cause of higher acceptance ratings.

Future research needs to empirically examine the effectiveness of the modes of customer contact during the different CSLC stages. During each stage of the customer life cycle, the customer contact modes can be examined individually. In addition, the interactions between these modes should be examined to detect synergies obtained by using multiple modes of customer contact. Effectiveness can be measured in a number of ways including accurate information transmitted to the customer, the proportion of present customers that are retained and the percentage of new ones recruited, the percentage of customers that can be sold higher-levels of or complementary services, the number of "hits" on the online users' community as well as the number of ideas obtained from this platform and integrated into company operations.

In conclusion, the primary purpose of this article is to propose the fit between the CSLC and a mix of customer contact technology modes can improve service delivery. Due to the increasing use of the Internet as a source of communication and the evolution of customer expectations [77,87], this is becoming an increasingly important research topic. Therefore, this article proposes a theoretical lens for studying the buyer-supplier relationship in a B2B context.

\section{REFERENCES}

[1] Central Intelligence Agency, "GDP - Composition by sector," 10 August, 2009, Accessed https://www.cia.gov/library/publications/ the-world-factbook/fields/2012.html.

[2] J. A. Fitzsimmons and M. J. Fitzsimmons, "Service management: Operations, strategy," Information Technology, McGraw-Hill, Irwin, 2008.

[3] IBM, "Why SSME?" 8 October, 2009, Accessed http:// www.ibm.com/ developerworks/spaces/ssme.

[4] R. B. Chase and U. M. Apte, "A history of research in service operations: What's the big idea?" Journal of Operations Management, Vol. 25, pp. 375-386, 2007.

[5] R. K. Rainer and E. Turban, "Introduction to information systems: Supporting and transforming business," John Wiley and Sons, 2008. 
[6] P. J. LaPlaca and J. M. Katrichis, "Relative presence of business-to-business research in the marketing literature," Journal of Business to Business Marketing, Vol. 16, pp. $1-22,2009$.

[7] A. Parasuraman and G. M. Zinkhan, "Web2.0 promises to enhance B2B activities," Journal of Academy of Marketing Science, Vol. 30, pp. 286-295, 2002.

[8] C. M. Froehle and A. V. Roth, "New measurement scales for evaluating perceptions of the technology-mediated customer service experience," Journal of Operations Management, Vol. 22, pp. 1-21, 2004.

[9] B. Ives and R. O. Mason, "Can information technology revitalize your customer service?" Academy of Management Executive, Vol. 4, pp. 52-69, 1990.

[10] R. B. Chase, "Where does the customer fit in a service operation?" Harvard Business Review, Vol. 56, pp. 137-142, 1978.

[11] T. Lee, J. Chun, J. Shim, and S. Lee, "An ontology-based product recommender system for B2B marketplaces," International Journal of Electronic Commerce, Vol. 11, pp. 125-155, 2006.

[12] B. Ives and T. Willinger, "To dell or be delled: A leading edge view of electronic commerce," University of Houston, Houston, 1999.

[13] B. H. Reber and S. Fosdick, "Building business relationships online: Relationship management in business-to-business e-commerce," Journal of Website Promotion, Vol. 1, pp. 13-29. 2005.

[14] J. Huang and C. Lin, "Empower internet services in hotel industry - A customer service life cycle concept," The Journal of American Academy of Business, Cambridge, Vol. 9, pp. 99-103, 2006.

[15] C. M. Goh, S. P. Lee, P. S. Tan, W. He, "Web 2.0 concepts and technologies for dynamic B2B integration," IEEE Conference on Emerging Technologies and Factory Automation, pp. 315-321, 2007.

[16] P. Anderson, "What is Web 2.0? ideas, technologies, and implications for education," 2007.

[17] J. Hammond, J. R. Rymer, R. Heffner, C. Schwaber, E. Driver, and J. Stone, "Developing enterprise Web 2.0 applications," Forrester Research, Inc., City, 2007.

[18] T. A. Yang, D. J. Kim, V. Dhalwani, and T. K. Vu, "The $8 \mathrm{C}$ framework as a reference model for collaborative value Webs in the context of Web 2.0," Proceedings of the 41st Hawaii International Conference on System Sciences, pp. 1-10, 2008.

[19] W. He, P. S. Tan, C. M. Goh, S. P. Lee, and E. W. Lee, "An investigative approach on improving B2B Interactions and communication capabilities for enterprise integration using Web 2.0 technologies," IEEE Conference on Emerging Technologies and Factory Automation, pp. 330-335, 2007.

[20] D. Iliyev, K. H. Choi, and K. J. Kim, "Dangers of applying Web 2.0 technologies in e-commerce solutions," International Conference on Information Science and Security, pp. 17-25, 2008.
[21] P. Chwelos, I. Benbasat, and A. S. Dexter, "Research report: Empirical test of an EDI adoption model," Information Systems Research, Vol. 12, pp. 304-321, 2001.

[22] M. Hughes, W. Golden, and P. Powell, "Inter-organisational ICT systems: The way to innovative practice for SMEs?" Journal of Small Business and Enterprise Development, Vol. 10, pp. 277-286, 2003.

[23] M. Quaddus, and G. Hofmeyer, "An investigation into the factors influencing the adoption of B2B trading exchanges in small businesses," European Journal of Information Systems, Vol. 16, pp. 202-215, 2007.

[24] W. H. DeLone, "Determinants of success for computer usage in small business," MIS Quarterly, Vol. 12, pp. 51-61, 1988.

[25] S. R. Magal, P. Kosalge, and N. M. Levenburg, "Using importance performance analysis to understand and guide e-business decision making in SMEs," Journal of Enterprise Information Management, Vol. 22, pp. 137-151, 2009.

[26] L. Rosencrance, "No smooth takeoff for US airways IT conversion. computerworld," Vol. 41, pp. 6, 2007.

[27] W. Kern, "Web 2.0 - end of accessibility? analysis of most common problems with Web 2.0 based applications regarding Web accessibility," International Journal of Public Information Systems, Vol. 2, pp. 131-154, 2008.

[28] W. Grey, T. Olavson, and D. Shi, "The role of e-marketplaces in relationship-based supply chains: A survey," IBM Systems Journal, Vol. 44, pp. 109-123, 2005.

[29] R. Shah, and P. T. Ward, "Defining and developing measures of lean production," Journal of Operations Management, Vol. 25, pp. 785-805, 2007.

[30] N. Thammakoranonta, A. Radhakrishnan, S. Davis, J. C. Peck, and J. L. Miller, "A protocol for the order commitment decision in a supply network," International Journal of Production Economics, Vol. 115, pp. 515-527, 2008.

[31] B. Massetti and R. W. Zmud, "Measuring the extent of EDI usage in complex organizations: Strategies and illustrative examples," MIS Quarterly, Vol. 20, pp. 331-345, 1996.

[32] R. Daft and R. Lengel, "Organizational information requirements, media richness and structural design," Management Science, Vol. 32, pp. 554-571, 1986.

[33] R. L. Daft and N. B. A Macintosh, "Tentative exploration into the amount and equivocality of information processing in organizational work units," Administrative Science Quarterly, Vol. 26, pp. 207-224, 1981.

[34] R. L. Daft, R. H. Lengel, and L. K. Trevino, "Message equivocality, media selection, and manager performance: Implications for information systems," MIS Quarterly, Vol. 11, pp. 354-366, 1987.

[35] K. K. Boyer, R. Hallowell, and A. V. Roth, "E-Services: Operating strategy - a case study and a method for analyzing operational benefits," Journal of Operations Management, Vol. 20, pp. 175-188, 2002.

[36] Oracle Welcome to Oracle Blogs, 2009, http://blogs. oracle.com/. 
[37] T. S. H. Teo and C. Ranganathan, "Adopters and non-adopters of business-to-business electronic commerce in Singapore," Information and Management, Vol. 42, pp. 89-102, 2004.

[38] S. K. Vickery, C. Droge, T. P. Stank, T. J. Goldsby, and R. E. Markland, "The performance implications of media richness in a business-to-business service environment: Direct versus indirect effects," Management Science, Vol. 50, pp. 1106-1119, 2004.

[39] J. E. G. Bateson, "Self-Service consumer: An exploratory study. journal of retailing," Vol. 61, pp. 49-76, 1985.

[40] K. R. Jayasimha and R. Nargundkar, "Adoption of self service bill payment technologies (SSBPTS: A conceptual model," Journal of Services Research, Vol. 6, pp. 119-134, 2006.

[41] S. Globerson and M. J. Maggard, "A conceptual model of self-service," International Journal of Operations and Production Management, Vol. 11, pp. 33-43, 1991.

[42] D. Troyer, "Bearings for greased motors," MROToday, April/May, 2005.

[43] J. M. Curran and M. L. Meuter, "Encouraging existing customers to switch to self-service technologies: Put a little fun in their lives," Journal of Marketing Theory and Practice, Vol. 15, pp. 283-298, 2007.

[44] L. Cohn, D. Brady, and D. Welch, "B2B: The hottest net bet yet?" Business Week, Vol. 1, No. 17, pp. 36-37, 2000.

[45] D. Pujari, "Self-Service with a smile? self-service technology (SST. encounters among canadian business-to-business," International Journal of Service Industry Management, Vol. 15, pp. 200-219, 2004.

[46] L. M. Huete and A. V. Roth, "The industrialisation and span of retail banks' delivery systems," International Journal of Operations and Production Management, Vol. 8, pp. 46-66, 1988.

[47] M. J.Bitner, A. L. Ostrom, and M. L. Meuter, "Implementing successful self-service technologies," Academy of Management Executive, Vol. 16, pp. 96-108, 2002.

[48] J. L. Hopkins and D. F. Kehoe, "Testing an interrelationship matrix-based method designed for assisting in e-marketplace selection," Electronic Markets, Vol. 17, pp. 210-230, 2007.

[49] E. D. Rosenzweig and A. V. Roth, "B2B seller competence: Construct development and measurement using a supply chain strategy lens," Journal of Operations Management, Vol. 25, pp. 1311-1331, 2007.

[50] A. Zaheer and N. Venkatraman, "Determinants of electronic integration in the insurance industry: An empirical test," Management Science, Vol. 40, pp. 549-566, 1994.

[51] P. O'Reilly and P. Finnegan, "B2B marketplaces sharing is/it infrastructures: An exploration of strategic technology alliances," Journal of Enterprise Information Management, Vol. 20, pp. 304-318, 2007.

[52] V. Cho, "Factors in the adoption of third-party B2B portals in the textile industry," Journal of Computer Information Systems, Vol. 46, pp. 18-31, 2006.
[53] K. J. Petersen, G. L. Ragatz, and R. M. Monczka, "An examinatino of collaborative planning effectiveness and supply chain performance," The Journal of Supply Chain Management: A Global Review of Purchasing and Supply, Vol. 41, pp. 14-25, 2005.

[54] M. R. Lind and R. W. Zmud, "Improving interorganizational effectiveness through voice mail facilitation of peer-to-peer relationships," Organization Science, Vol. 6, pp. 445-461, 1995.

[55] A. V. Roth and L. J. Menor, "Insights into service operations management: A research agenda," Production and Operations Management, Vol. 12, pp. 145-164, 2003.

[56] A. R. Dennis and S. T. Kinney, "Testing media richness theory in the new media: The effects of cues, feedback, and task equivocality," Information Systems Research, Vol. 9, pp. 256-274, 1998.

[57] K. Zhu and K. L. Kraemer, "e-Commerce metrics for net-enhanced organizations: Assessing the value of e-commerce to firm performance in the manufacturing sector," Information Systems Research, Vol. 13, pp. 275-295, 2002.

[58] J. N. Sheth and A. Sharma, "The impact of the product to service shift in industrial markets and the evolution of the sales organization," Industrial Marketing Management, Vol. 37, pp. 260-269, 2008.

[59] P. Oliveira, A. V. Roth, and W. Gilland, "Achieving competitive capabilities in e-services," Technological Forecasting and Social Change, Vol. 69, pp. 721-739, 2002.

[60] A. Barua, S. Ravindran, and A. B. Whinston, "Efficient selection of suppliers over the internet," Journal of Management Information Systems, Vol. 13, pp. 117-137, 1997.

[61] E. Ambrose, D. Marshall, B. Fynes, and D. Lynch, "Communication media selection in buyer-supplier relationships," International Journal of Operations and Production Management, Vol. 28, pp. 360-379, 2008.

[62] D. E. Leidner and T. Kayworth, "Review: A review of culture in information systems research: Toward a theory of information technology culture conflict," MIS Quarterly, Vol. 30, pp. 357-399, 2006.

[63] U. Schultze and W. J. Orlikowski, “A practice perspective on technology-mediated network relations: The use of internet-based self-serve technologies," Information Systems Research, Vol. 15, pp. 87-106, 2004.

[64] E. Bartezzaghi and S. Ronchi, "E-Sourcing in a buyeroperator-seller perspective: Benefits and criticalities," Production Planning and Control, Vol. 16, pp. 405-412, 2005.

[65] Q. Dai and R. J. Kauffman, "Business models for internet-based B2B electronic markets," International Journal of Electronic Commerce, Vol. 6, pp. 41-72, 2002.

[66] L. M. Ellram, W. L. Tate, and C. Billington, "Offshore outsourcing of professional services: A transaction cost economics perspective," Journal of Operations Management, Vol. 26, pp. 148-163, 2008.

[67] G. Chakraborty, V. Lala, and D. Warren, "What do cus- 
tomers consider important in B2B Websites?" Journal of Advertising Research, Vol. 43, pp. 50-61, 2003.

[68] G. Piccoli, B. R. Spalding, and B. Ives, “A framework for improving customer service through information technology," Cornell Hotel and Restaurant Administration Quarterly, Vol. 42, pp. 39, 2001.

[69] T. Baumgartner, R. H. John, and T. Naucler, "Transforming sales and service," McKinsey Quarterly, pp. 80-91, 2005.

[70] J. A. Buzacott, "Service system structure," International Journal of Production Economics, Vol. 68, pp. 15-27, 2000.

[71] J. L. Hopkins and D. F. Kehoe, "The theory and development of a relationship matrix-based approach to evaluating e-marketplaces," Electronic Markets, Vol. 16, pp. 245-260, 2006.

[72] M. J. Cotteleer, C. A. Cotteleer, and A. Prochnow, "Cutting checks: Challenges and choices in B2B e-payments," Communications of the ACM, Vol. 50, pp. 56-61, 2007.

[73] T. Shifrin, “'Bad design' B2B Websites hits sales," Computer Weekly, June 13-14, 2006.

[74] M. Petre, S. Minocha, and D. Roberts, "Usability beyond the website: An empirically-grounded e-commerce evaluation instrument for the total customer experience," Behaviour and Information Technology, Vol. 25, pp. 189-203, 2006.

[75] T. W. Malone, J. Yates, and R. I. Benjamin, "Electronic markets and electronic hierarchies," Communications of the Association for Computing Machinery, Vol. 30, pp. 484-497, 1987.

[76] R. Brennan, L. Canning, and R. McDowell, "Price-setting in business-to-business markets," Marketing Review, Vol. 7, pp. 207-234, 2007.

[77] E. K. Clemons, S. P. Reddi, and M. C. Row, "The impact of information technology on the organization of economic activity: The move to the middle hypothesis,"
Journal of Management Information Systems, Vol. 10, pp. 9-35, 1993.

[78] A. V. Roth and C. H. Mason, "The right path to scm-crm integration," City, 2008.

[79] T. M. Laseter and S. E. Bodily, "Strategic indicators of B2B e-marketplace financial performance," Electronic Markets, Vol. 14, pp. 322-332, 2004.

[80] R. Gulati, and J. Garino, "Get the right mix of bricks and clicks," Harvard Business Review, Vol. 78, pp. 107-114, 2000.

[81] M. G. Jacobides, "Industry change through vertical disintegration: How and why markets emerged in mortgage banking," Academy of Management Journal, Vol. 48, pp. 465-498, 2005.

[82] N. Rackoff and C. Wiseman, "Information systems for competitive advantage: Implementation of a planning process,” MIS Quarterly, Vol. 9, pp. 285-294, 1985.

[83] P. Walley and V. Amin, "Automation in a customer contact environment," International Journal of Operations and Production Management, Vol. 14, pp. 86-100, 1994.

[84] D. Brandon, "The future of automated forecasts and ordering," Chain Store Age, Vol. 83, pp. 134, 2007.

[85] D. Tan and J. T. Mahoney, "Why a multinational firm chooses expatriates: Integrating resource-based, agency and transaction cost perspectives," Journal of Management Studies, Vol. 43, pp. 457-484, 2006.

[86] M. Beckinsale, M. Levy, and P. Powell, "Exploring internet adoption drivers in SMEs," Electronic Markets, Vol. 16, pp. 361-370, 2006.

[87] S. Leek, P. Naude, and P. W. Turnbull, "Interactions, relationships and networks in a changing world," Industrial Marketing Management, Vol. 32, pp. 87-90, 2003.

[88] S. Bandyopadhyay, J. M. Barron, and A. R. Chaturvedi, "Competition among sellers in online exchanges," Information Systems Research, Vol. 16, pp. 47-60, 2005. 